\title{
Identifikasi Ekspresi Gen Myc pada Subkultur MCF-7 Breast Cancer Cell Line dengan Sel Punca
}

\author{
Yuastika Puspita Sari ${ }^{1}$, Hirowati Ali $^{2}$, Aswiyanti Asri $^{3}$
}

\begin{abstract}
Abstrak
Kanker payudara yang paling banyak ditemukan adalah subtipe luminal A dengan karakteristik Estrogen Reseptor+. Subjek penelitian akan diwakili oleh cell line MCF-7 dan Umbilical Cord Blood Mesenchymal Stem Cell (UCBMSC). Over expression Myc pada kanker payudara mengakibatkan sel kanker menjadi lebih invasif dan terjadi resistensi terhadap terapi hormonal. Tujuan penelitian ini adalah mengidentifikasi ekspresi gen Myc pada cell line MCF-7 sebelum dan sesudah pemberian sel punca. Penelitian ini menggunakan desain experimental secara in vitro. Sampel menggunakan MCF-7 dan sel punca yang dibagi menjadi 4 kelompok, yaitu K1 (kelompok kontrol MCF-7), K2 (kelompok kontrol sel punca), P1 (perlakuan subkultur MCF-7 dengan sel punca inkubasi 24 jam), dan P2 (inkubasi 48 jam). Kemudian, dilakukan isolasi RNA, sintesis CDNA, dan ekspresi Myc diperiksa menggunakan PCR dan elektroforesis. Analisa data yang digunakan adalan One Way ANOVA dan post-hoc LSD. Hasil analisis bivariat didapatkan $\mathrm{p}<0,05$. Dari uji post-hoc LSD tidak ditemukan perbedaan yang bermakna antara $\mathrm{K} 1$ dengan $\mathrm{P} 1$, $\mathrm{K} 1$ dengan P2, dan K2 dengan P2. Namun, tetap ditemukan perbedaan yang bermakna antara K2 dengan P1 dan P1 dengan P2. Simpulan penelitian ini adalah tidak terdapat perbedaan bermakna ekspresi gen Myc pada subkultur antara MCF-7 breast cancer cell line dengan pemberian sel punca mesenkimal.
\end{abstract}

Kata kunci: Myc, MCF-7, sel punca

\section{Abstract}

The most common type of breast cancer is the luminal subtype A with Estrogen Receptor + . The subject of this study is represented by MCF-7 cell line and Umbilical Cord Blood Mesenchymal Stem Cell (UCBMSC). Myc over expression resulted in more invasive cancer cells and resistance to hormonal therapy. The objective of this study was to identify the expression of myc on MCF-7 before and after stem cell intervention. This research used experimental design with in vitro approach. MCF-7 and stem cells were used and divided into 4 groups, named K1 (MCF-7 control group), K2 (stem cell control group), P1 (MCF-7 with stem cells incubation for $24 \mathrm{~h}$ treatment group) and P2 (incubation for 48 h). RNA isolation, cDNA synthesis, and Myc expression were examined by using PCR and electrophoresis. One Way Anova and post-hoc LSD were used as data analysis method. The results of the bivariate analysis is $p<0.05$. The post-hoc LSD showed that there are no significant difference between $K 1$ and $P 1, K 1$ and $P 2$, $K 2$ and P2. The result was the significant difference between $K 2$ and $P 1$ also $P 1$ and P2. The conclusion is no significant difference of Myc expression in co-cultured MCF-7 breast cancer cell line with mesenchymal stem cell intervention.

Keywords: Myc, MCF-7, stem cells

Affiliasi penulis: 1. Prodi Kedokteran Fakultas Kedokteran Universitas Andalas Padang (FK Unand), 2. Bagian Biokimia FK Unand, 3. Bagian Patologi Anatomi FK Unand
Korespondensi: Yuastika Puspita Sari, Email: yuastikapuspitasari@gmail.com,Telp: 085664355074 


\section{PENDAHULUAN}

Kanker payudara merupakan salah satu penyebab kematian utama pada wanita di dunia maupun Indonesia. Menurut World Health Organization (WHO) terdapat sekitar 1,5 juta wanita yang menderita kanker payudara dengan angka kematian sekitar 570.000 wanita pada tahun $2015{ }^{1}$ Berdasarkan Pathological Based Registration, kanker payudara menempati urutan pertama dengan angka kejadian 12/100.000 wanita di Indonesia. ${ }^{2}$

Keganasan pada kanker payudara terjadi akibat terganggunya sistem pertumbuhan sel dalam jaringan payudara yang berasal dari lobulus ataupun duktus. ${ }^{3}$ Klasifikasi keganasan ini dapat digolongkan menurut observasi morfologis, grade tumor, histologis, status nodus limfe, dan molekular. ${ }^{2}$ Subtipe molekular kanker payudara dapat dibagi menjadi subtipe Luminal A, Luminal B, Claudin low, Basal like Breast Cancer, dan HER 2 over expression. ${ }^{4}$ Luminal A merupakan salah satu subtipe kanker payudara yang paling sering ditemukan. Sekitar 50-60\% populasi penderita kanker payudara termasuk ke dalam subtipe Luminal $A^{5}$ Subtipe ini menunjukkan hasil pemeriksaan marker ER(+), PR(+), HER2(-) dan Ki67 rendah. ${ }^{4}$ Pasien dengan kanker payudara luminal $A$ mempunyai prognosis yang lebih baik dengan angka relaps lebih rendah daripada subtipe yang lain. Sekitar $29 \%$ pasien penderita kanker payudara subtipe luminal $A$ memiliki angka rekuren yang lebih tinggi karena terjadinya resisten hormon relatif. ${ }^{5}$

Gen Myc merupakan salah satu protoonkogen yang menyandikan faktor transkripsi dan berperan penting dalam regulasi pertumbuhan sel, proliferasi, diferensiasi dan apoptosis sel. ${ }^{6}$ Myc merupakan gen yang responsif terhadap estrogen. ${ }^{7}$ Ekspresi Myc diregulasi oleh estrogen melalui jalur phosphatidy linositol-4,5-biphosphate 3 kinase (PI3K). Ekspresi gen Myc yang berlebihan terjadi apabila gen Myc mengalami mutasi menjadi onkogen yang menyebabkan kerusakan DNA dan pertumbuhan sel menjadi tidak terkontrol. ${ }^{8}$ Myc memiliki peran penting dalam tumerogenesis dan sangat berperan dalam kelangsungan hidup sel kanker yang resisten terhadap terapi anti kanker. Ekspresi gen Myc yang berlebihan terjadi sekitar $30-50 \%$ sel tumor grade tinggi kanker payudara. $^{7}$ Myc mRNA juga berhubungan secara signifikan dengan gen pada translasi dan metabolisme protein seluler pada kanker payudara dengan ER $(+){ }^{8}$ Ekspresi Myc yang berlebihan telah diamati pada MCF-7, model sel kanker payudara ER+. ${ }^{7}$

Terapi hormon cukup efektif dalam mengobati kanker payudara dengan ER+, tetapi $29 \%$ dari semua kasus kanker payudara subtipe ini tidak memberikan respon terhadap pengobatan dan sering terjadi resistensi terhadap terapi. ${ }^{5}$ Ekspresi berlebihan gen Myc pada sekitar 11\% kanker payudara subtipe Luminal A juga memberikan prognosis yang buruk. ${ }^{9}$ Data penelitian menunjukan bahwa apabila gen Myc diekspresikan berlebihan, hal ini dapat menyebabkan resistensi terapi pada kanker payudara $\mathrm{ER}+{ }^{7}$

Pilihan modalitas terapi untuk kanker payudara subtipe luminal A sampai saat ini masih kontroversi. ${ }^{9}$ Salah satu terapi baru yang sedang dikembangkan pada penderita kanker payudara adalah dengan pemberian sel punca (stem cell therapeutic) yang memiliki kemampuan berdiferensiasi dan membelah diri (self renewal). Sel punca merupakan sel yang menjadi awal mula dari pertumbuhan sel lain yang menyusun seluruh tubuh manusia. Sel punca dewasa dapat dibagi menjadi sel punca hematopoietic, jantung, kulit, mesenkimal, jaringan kulit dan jaringan saraf. ${ }^{10}$ hUCMSCs dapat memproduksi interferon beta (INF- $\beta$ ) yang memiliki kemampuan menghambat pertumbuhan sel kanker payudara melalui kedua jalur apoptosis ekstrinsik maupun intrinsik. Pada penelitian in-vitro, diketahui bahwa INF- $\beta$ berperan sebagai efek inhibitor yang kuat pada pertumbuhan sel tumor dan menyebabkan kematian sel. ${ }^{11}$

Berdasarkan pemaparan latar belakang permasalahan diatas, maka perlu dilakukan penelitian untuk mengidentifikasi ekspresi gen myc pada subkultur MCF-7 breast cancer cell line dengan sel punca.

\section{METODE}

Penelitian experimental dengan studi in vitro telah dilakukan pada September 2017 - Mei 2018 di Laboratorium Biomedik Fakultas Kedokteran Universitas Andalas, Padang, Sumatera Barat. Populasi dan sampel penelitian ini adalah cell line 
MCF-7 sebagai model sel kanker payudara subtipe Luminal A yang berhasil ditumbuhkan di Laboratorium Kultur Sel Biomedik Fakultas Kedokteran Universitas Andalas. Sel MCF-7 diperoleh dari Laboratorium Kultur Sel Fakultas Kedokteran UNPAD (Universitas Padjadjaran) Bandung yang disubkultur dengan sel punca dari MSI UPT Teknologi Kedokteran Sel Punca RSCM.

Sampel penelitian yang dipilih adalah Cell line MCF-7 dan sel punca yang memenuhi kriteria inklusi dan tidak memiliki kriteria eksklusi. Kriteria inklusi subjek: sel yang terlihat sehat dan tanpa kontaminasi secara mikroskopis, tumbuh dan berkembang dengan baik, serta sel yang intak. Kriteria eksklusi subjek: sel yang mati dalam tahap pengembangan sel, terlihat mengapung pada saat dilihat menggunakan mikroskop inverted dan terkontaminasi bakteri dan jamur.

Sampel menggunakan kultur sel MCF-7 dan sel punca yang dibagi menjadi 4 kelompok, yaitu $\mathrm{K} 1$ (kelompok kontrol MCF-7), K2 (kelompok kontrol sel punca), P1 (perlakuan pada MCF-7 dengan pemberian sel punca yang diinkubasi selama 24 jam), dan P2 (inkubasi selama 48 jam). Kemudian, dilakukan isolasi RNA, sintesis cDNA, dan diperiksa ekspresi gen Myc dengan menggunakan PCR dan elektroforesis. Analisa data yang digunakan adalan One Way ANOVA dan post-hoc LSD.

Primer yang digunakan untuk pemeriksaan PCR adalah Myc, (F) 5' TTCTCTGCTCTCCTCGACGG-3' dan (R) 5'TGCTGATGTGTGGAGACGTG -3' ; GAPDH, (F) 5'AATGGGGTGATGCTGGTG-3' dan (R) 5'GGAAGGGGCGGAGATG-3'.

HASIL

Tabel 1. Ekspresi Myc pada empat kelompok sampel

\begin{tabular}{ccc}
\hline Kelompok & (p) & Kemaknaan \\
\hline K1 vs K2 & 0,054 & Tidak Bermakna \\
K1 vs P1 & 0,191 & Tidak Bermakna \\
K1 vs P2 & 0,275 & Tidak Bermakna \\
K2 vs P1 & 0,009 & Bermakna \\
K2 vs P2 & 0,253 & Tidak Bermakna \\
P1 vs P2 & 0,034 & Bermakna \\
\hline
\end{tabular}

Ket: $\mathrm{K} 1=$ kontrol MCF-7, $\mathrm{K} 2=$ kontrol sel punca $\mathrm{P} 1=$ kelompok perlakuan subkultur MCF-7 dengan sel punca inkubasi 24 jam, P2 = kelompok perlakuan subkultur MCF-7 dengan sel punca inkubasi 48 jam.
Penelitian eksperimental ini bertujuan untuk mengidentifikasi ekspresi gen Myc pada MCF-7 breast cancer cell line yang disubkultur dengan Umbilical Cord Blood Mesenchymal Stem Cell (UCBMSC). Hasil visualisasi dari pemeriksaan elektroforesis pada Gambar 1 menunjukkan bahwa GAPDH dan Myc terekspresikan dan hasil tersebut dapat menggambarkan ekspresi Myc pada sampel perlakuan. Ketebalan band yang diukur dalam penelitian ini adalah gen Myc pada 256 bp dan GAPDH pada 119 bp. Pada gambar tersebut dapat terlihat perbedaan ketebalan band pada masingmasing kelompok yang selanjutnya dapat dinilai secara semi kuantitatif.

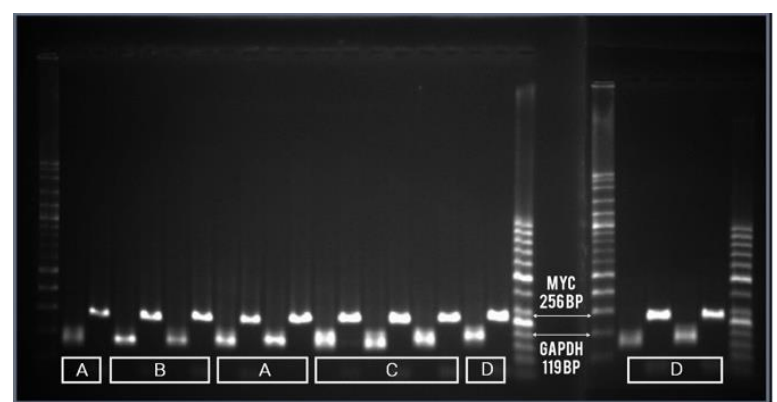

Gambar 1. Hasil pemeriksaan elektroforesis GAPDH dan Myc yang dilihat dengan sinar UV

Ket: $A=$ sampel MCF-7, $B=$ sampel MSC dalam medium a-MEM, $\mathrm{C}=$ sampel MSC-MCF7 dalam medium $\alpha$-MEM 24 jam, D = sampel MSC-MCF7 dlm medium $\alpha$ - MEM 48 jam.

Ketebalan band yang ada pada hasil visualisasi diukur dengan menggunakan Image-J software sehingga didapatkan hasil dalam bentuk semi kuantitatif. Hasil yang didapatkan akan menunjukkan bahwa semakin tinggi densitas band maka semakin tinggi ekspresi gen pada sampel. Selanjutnya dilakukan uji densitometri pada Myc dan GAPDH yang diolah dengan menggunakan Image-J software. GAPDH berperan sebagai housekeeping gene atau kontrol internal pada Myc, sehingga untuk interpretasi dari Myc menggunakan Myc/GAPDH.

Berdasarkan Tabel 1 terlihat perbedaan ketebalan band pada masing-masing kelompok tetapi belum dapat dinilai secara kuantitatif. Hasil visualisasi dari pemeriksaan elektroforesis menunjukkan bahwa GAPDH dan Myc terekspresikan pada sampel perlakuan. Ekspresi gen Myc tertinggi ditunjukkan oleh 
kelompok kontrol sel punca, dan ekspresi terendah ditunjukkan oleh kelompok perlakuan subkultur MCF-7 dengan sel punca yang diikubasi selama 24 jam.

\section{Analisis Data}

Data Myc pada kelompok kontrol dan perlakuan ddianalisis secara komputerisasi. Didapatkan nilai rerata dan standar deviasi Myc pada kelompok kontrol dan perlakuan. Selanjutnya dilakukan uji normalitas data menggunakan Shapiro-Wilk Test didapatkan nilai $p>0.05$, berarti data terdistribusi secara normal. Pada uji homogenitas menunjukkan data homogen (nilai $p>0,05)$ sehingga dapat dilanjutkan dengan uji parametrik.

Tabel 2. Nilai rerata dan standar deviasi ekspresi Myc

\begin{tabular}{ccc}
\hline Kelompok & $\bar{x} \pm$ SD & p \\
\hline K1 & $0,84 \pm 0,23$ & \\
K2 & $1,15 \pm 0,17$ & 0,038 \\
P1 & $0,67 \pm 0,02$ & \\
P2 & $0,98 \pm 0,09$ & \\
\hline
\end{tabular}

Analisis selanjutnya untuk melihat hasil signifikansi perbedaan perlakuan maka digunakan analisa statistik One Way ANOVA dan dilanjutkan. Pada uji One Way ANOVA didapatkan perbedaan yang signifikan, yaitu dengan nilai 0,038 ( $p<0,05)$. Analisa dilanjutkan dengan uji Post-Hoc LSD seperti yang disajikan pada Tabel 3 .

Tabel 3. Perbedaan ekspresi gen Myc dengan menggunakan uji Post-Hoc LSD.

\begin{tabular}{ccccc}
\hline \multicolumn{5}{c}{ Kelompok } \\
Sampel & $\mathbf{( K 1 )}$ & $\mathbf{( K 2 )}$ & $\mathbf{( P 1 )}$ & $\mathbf{( P 2 )}$ \\
\hline 1 & 1,09 & 1,03 & 0,66 & 0,89 \\
2 & 0,64 & 1,27 & 0,69 & 1,07 \\
3 & 0,81 & & 0,67 & 0,99 \\
\hline
\end{tabular}

Hasil uji lanjutan pada Tabel 3 menunjukkan bahwa terdapat perbedaan yang bermakna antara kelompok kontrol 2 dengan kelompok perlakuan 1, dan perlakuan 1 dengan perlakuan $2(p<0,05)$. Tetapi tidak terdapat perbedaan antara kontrol 1 dengan kontrol 2, kontrol 1 dengan perlakuan 1, kontrol 1 dengan perlakuan 2 dan kontrol 2 dengan perlakuan 2 .

\section{PEMBAHASAN}

Mekanisme karsinogenesis kanker payudara ditandai dengan adanya perubahan seluler. Kanker terjadi akibat adanya perubahan protoonkogen menjadi onkogen, gen supresor tumor, gen DNA repair, dan gen micro DNA. ${ }^{8}$ Perubahan protoonkogen menjadi onkogen disebabkan karena aktivasi dengan cara amplifikasi gen. Banyak sel kanker mengandung kopi oncogen, misalnya kanker payudara sering mengamplifikasi Myc. ${ }^{6}$ Beberapa bukti menunjukkan bahwa c-Myc dapat menyebabkan transformasi melalui fungsinya sebagai aktivator transkripsi urutan tertentu sehingga c-Myc dapat menyebabkan transformasi dengan mengaktifkan satu set gen pilihan yang memainkan peran utama dalam transformasi maligna. ${ }^{12}$

Pada penelitian ini didapatkan ekspresi gen Myc, baik pada kelompok kontrol maupun kelompok yang diberi perlakuan. Terdapat perbedaan ekspresi gen Myc yang tidak bermakna antara kontrol MCF-7 dengan kontrol sel punca. Tidak ada angka pasti atau ekspresi pasti Myc dalam keadaan normal, tetapi untuk mengetahui Myc overexspression adalah dengan melihat kelompok kontrol MCF-7. Efek sel punca pada sel kanker payudara masih kontroversial. Pada penelitian ini ditemukan bahwa ekspresi gen Myc pada Mesenchymal stem cell (MSC) lebih tinggi dari pada MCF-7. Hal ini sesuai dengan penelitian oleh Rhodes et al (2010). yang menunjukkan bahwa MSC secara signifikan memiliki daya proliferasi sel yang lebih tinggi dibandingkan dengan sel MCF-7. ${ }^{13}$ Akumulasi dari B-catenin oleh MSC menyebabkan terjadinya proliferasi sel sehingga meningkatkan ekspresi gen Myc. ${ }^{14}$

Penelitian ini menunjukkan bahwa tidak ada perbedaan yang bermakna antara ekspresi gen Myc pada kelompok cell line MCF-7 sebagai kelompok kontrol dengan cell line MCF-7 yang disubkultur dengan sel punca sebagai kelompok perlakuan. Pada kelompok yang diberi perlakuan 1, perlakuan 2 dan kontrol 1 memiliki hasil yang lebih rendah dibanding kelompok kontrol 2 , serta didapatkan bahwa perlakuan 1 memiliki nilai paling rendah, yaitu $0,67 \pm 0,02$. Berdasarkan hasil penelitian sebelumnya oleh Adelipour et al (2017), bahwa penggunaan sel punca 
mesenkimal pada sel kanker payudara menyebabkan penurunan ekspresi gen Myc. Walaupun tidak mungkin MSC secara langsung mempengaruhi ekspresi gen Myc, tetapi penurunan ekspresinya dapat dihubungkan dengan regresi dan apoptosis sel tumor. Sel punca dapat menimbulkan cell cycle arrest dan meningkatkan apoptosis sel kanker. ${ }^{15}$ Penelitian invitro oleh Shen et al (2015) menunjukkan bahwa INF- $\beta$ pada MSC berperan sebagai efek inhibitor yang kuat pada pertumbuhan sel tumor dan menyebabkan kematian sel. ${ }^{11}$

Pada penelitian ini menunjukkan hasil yang bermakna antara kontrol 2 dengan perlakuan 2. MSC mensekresikan TGF- $B$ dan menstimulasi aktivitas jalur sinyal Wnt dengan mendorong translokasi ß-catenin ke nukleus dan meningkatkan kecepatan kerja gen target seperti MMP2, c-Myc, dan cyclin D1. ${ }^{16}$ TGF-B pada stadium awal pertumbuhan sel kanker payudara berfungsi sebagai tumor supresor dan memberi efek antiproliferasi. Sedangkan pada stadium lanjut, TGF-ß berperan sebagai onkogen dan menyebabkan proliferasi sel kanker dan metastasis. TGF-ß membentuk hubungan dengan onkogen lain seperti $c$ Myc dalam memodulasi ekspresi gen-gen yang berhubungan dengan tumerogenesis. ${ }^{17}$

Pada kelompok perlakuan dengan pemberian sel punca pada MCF-7 yang diinkubasi selama 24 jam dan 48 jam didapatkan adanya perbedaan yang signifikan. Hal tersebut menunjukkan bahwa terdapat perbedaan yang bermakna pada waktu inkubasi yang diberikan. Pada penilitian ini terjadi penurunan ekspresi gen Myc pada inkubasi 24 jam, kemudian meningkat setelah inkubasi selama 48 jam. Mekanisme yang mendasari penghentian pertumbuhan sel tumor payudara yaitu terjadinya cell cycle arrest, induksi apoptosis sel tumor, dan penekanan aktivitas $\mathrm{PI} 3 \mathrm{~K}$ dan protein kinase Akt. hUCMSC memiliki kemampuan menghentikan jalur sinyal Akt dan PI3K sehingga menghambat proliferasi sel tumor. ${ }^{18}$

Penelitian ini memiliki beberapa keterbatasan, baik dari uji ekspresi gen Myc maupun metode yang digunakan. Agar data yang didapatkan kuantitatif, maka uji ekspresi gen Myc bisa dilakukan menggunakan Real Time PCR. Tempat biakan sel tidak memenuhi standar sehingga salah satu sampel mengalami kontaminasi, sehingga tidak dapat digunakan untuk tahap selanjutnya.

\section{SIMPULAN}

Terdapat ekspresi gen Myc pada cell line MCF7, sel punca, dan subkultuf MCF-7 dengan sel punca yang diinkubasi selama 24 dan 48 jam.

Tidak terdapat perbedaan ekspresi gen myc yang bermakna secara signifikan antara kelompok MCF-7 sebelum dan sesudah pemberian sel punca.

\section{DAFTAR PUSTAKA}

1. World Health Organization (WHO). Cancer: Breast Cancer. WHO; 2015 (diunduh11 September 2017). Tersedia dari: http://www.who.int/cancer/ prevention/diagnosis-screening/breast-cancer/en/

2. Komite Nasional Penanggulangan Kanker. Pedoman nasional pelayanan kedokteran kanker payudara. Kementerian Kesehatan RI (diunduh 11 September 2017) Tersedia dari: http://kanker. kemkes.go.id/guidelines/PPKPayudara.pdf

3. American Cancer Society. Breast cancer facts and figures 2017-2018. (diunduh15 Desember 2017). Tersedia dari: https://www.cancer.org/content/ dam/cancer-org/research/cancer-facts-andstatistics/breast-cancer-facts-and-figures/breastcancer-facts-and-figures-2017-2018.pdf

4. Holliday DL, Speirs V. Choosing The right cell line for breast cancer research. BioMed Central. 2011;13:1-5

5. Yersal O, Barutca S. Biological subtypes of breast cancer: prognostic and therapeutic implications. World Journal of Clinical Oncology. 2014; 5 (3): 412-25.

6. Aman RA, Gondhowiardjo $S$, Rachman A, Suriadireja A, Syahruddin E, Tobing DL, et al. IImu dasar onkologi. Edisi ke-3. Jakarta: Fakultas Kedokteran Universitas Indonesia; 2010.hlm.36-65.

7. Fallah $Y$, Brundage J, Allegakoen $P$, Shajahan-haq AN. MYC-Driven pathways in breast cancer subtypes. Biomolecules. 2017;1-6.

8. Green AR, Aleskandarany MA, Agarwal D, Elsheikh S, Nolan CC, Diez-rodriguez M, et al. MYC Functions are specific in biological subtypes 
of breast cancer and confers resistance to endocrine therapy in luminal tumours. BJC. 2016;114(8):917-28.

9. Clarke R, Tyson JJ, Dixon M. Endocrine resistance in breast cancer. Mol cell endorinol. 2015; 418 (3): 220-34.

10. Halim D, Murti H, Sandra F, Boediman ATD, Setiawan BS. Stem cell dasar teori dan aplikasi klinis. Jakarta: Erlangga; 2010. hlm.4-125.

11. Shen CJ, Chan TF, Chen CC, Hsu YC, Long CY, Lai CS. Human umbilical cord matrix-derived stem cells expressing interferon- $\beta$ gene inhibit breast cancer cells via apoptosis. Oncotarget. 2015;7(23):34172-8.

12. Chi V. Dang. Myc on the path to cancer. NIH Public Access. 2013;149(1):22-35.

13. Rhodes LV, Antoon JW, Muir SE, Elliot S, Beckman BS, Burow ME. Effects of human mesenchymal stem cells on ER-positive human breast carcinoma cells mediated through ER-SDF1/CXCR4 crosstalk. Molecular Cancer. 2010;9:295.

14. Chen J, Crawford R, Chen C, Xiao Y. The Key Regulatory Roles of the PI3K/Akt Signaling
Pathway in the Functionalities of Mesenchymal Stem Cells and Applications in Tissue Regeneration. Tissue Engineering. 2012; 19 (6): 516-28.

15. Adelipour M, Babaei F, Mirzababaei M, Allameh A. Correlation of micro vessel density and c-Myc expression in breast tumor of mice following mesenchymal stem cell therapy. Tissue and Cell. 2017;49(2):315-22.

16. Wang W, Zhong W, Yuan J, Yan C, Hu S, Tong Y, et al. Involvement of $\mathrm{Wnt} / \beta$-catenin signaling in the mesenchymal stem cells promote metastatic growth and chemoresistance of cholangiocarcinoma. Oncotarget. 2015 ; 6 (39): 42276-89.

17. Patel SA, Heinrich AC, Reddy BY, Srinivas B, Heidaran N, Rameshwar P. Breast cancer biology: the multifaceted roles of mesenchymal stem cells. Journal of Oncology. 2008. P.1-7.

18. Ma Y, Hao X, Zhang S, Zhang J. The in vitro and in vivo effects of human umbilical cord mesenchymal stem cells on the growth of breast cancer cells. Breast Cancer Res Treat. 2012;133(2):473-85. 